\title{
Long-term lead intoxication of Griffon Vulture (Gyps fulvus Hablizl, 1783) supposedly the result of illegal shooting
}

\author{
Anton Stamenov ${ }^{1 *}$, Ivanka Lazarova ${ }^{2}$, Volen ArkUmarev ${ }^{1}$, \\ Stefka Dimitrova ${ }^{3}$, Nikolay Terziev ${ }^{1}$, Atanas Delchev ${ }^{1} \&$ \\ Dobromir DoBREV ${ }^{1}$
}

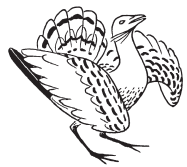

Received: March 23, 2021 - Revised: May 30, 2021 -Accepted: May 31, 2021

Stamenov, A., Lazarova, I., Arkumarev, V., Dimitrova, S., Terziev, N., Delchev, A. \& Dobrev, D. 2021. Long-term lead intoxication of Griffon Vulture (Gyps fulvus Hablizl, 1783) supposedly the result of illegal shooting. - Ornis Hungarica 29(1): 179-185. DOI: 10.2478/orhu-2021-0014

\begin{abstract}
The European Griffon Vulture Gyps fulvus is a large-sized scavenger exploiting carcasses of livestock and wild ungulates and thus having a paramount importance in the natural ecosystems. In this study, we report on an adult Griffon Vulture detected with lead levels in the bones over the threshold. After two years of tracking, the bird died. The corpse's clinical examination and radiography detected the presence of two embedded lead pellets from a healed gunshot wound in its right wing. Quantitative laboratory analysis of lead in bone and liver samples evidencing subclinical/chronic lead intoxication of the Griffon Vulture could potentially be a result of the longterm exposure to the lead originating from the pellets in its wing.
\end{abstract}

Keywords: scavenger, toxicity, heavy metal, Eastern Rhodopes, embedded lead pellets

Összefoglalás A fakó keselyü (Gyps fulvus) egy nagytestü, dögevő ragadozómadár-faj, amely haszon- és vadállatok elhullott tetemein táplálkozik és ezáltal fontos szerepet tölt be a természetes ökoszisztémában. Ebben a tanulmányban egy olyan öreg példány elhullásáról számolunk be, amelynek véréből már egy korábbi mintavétel során is határértéken felüli ólomkoncentráció mutatkozott. A műholdas jeladóval ellátott egyed két évvel később elpusztulva került meg. A tetem boncolását és röntgenvizsgálatát követően bebizonyosodott, hogy a madár jobb szárnyában két, korábbi lövésből származó ólomsörét volt beágyazódva. A laborvizsgálatok során a fakó keselyü csontszövetéből és májából származó minták egyaránt szubklinikai/krónikus ólommérgezésre utaló koncentrációt mutattak, amelyet feltehetően a madár szárnyában hosszú ideig jelenlévő sörétszemek okoztak.

Kulcsszavak: dögevők, toxicitás, nehézfémek, Kelet-Rodope, beágyazódott ólomsörét

${ }^{1}$ Bulgarian Society for the Protection of Birds /BirdLife Bulgaria, Yavorov 71, 1111 Sofia, Bulgaria

${ }^{2}$ Faculty of Veterinary Medicine, Trakia University, Stara Zagora 6000, Bulgaria

${ }^{3}$ Wildlife Rehabilitation and Breeding Center - Green Balkans - Stara Zagora NGO, 6006 P. Box: 27 Stara Zagora, Bulgaria

*corresponding author, e-mail: anton.stamenov@bspb.org

\section{Introduction}

The Eurasian Griffon Vulture Gyps fulvus is a large Old World vulture that scavenges carcasses of livestock and wild ungulates (DeVault et al. 2003). Its breeding distribution extends from Kazakhstan and Nepal in the east, throughout the Caucasus, southern Europe and the Iberian Peninsula to the west (BirdLife International 2020). Adult Griffon Vultures 
are mostly resident, while juveniles are primarily nomadic, some exhibiting migratory behaviour, overwintering in Africa and the Middle East (del Hoyo et al. 1994, McGrady \& Gavashelishvili 2006, Arkumarev et al. 2019). On the Balkan Peninsula, the species breeds in Bulgaria, Greece, North Macedonia, Serbia and Croatia (Sušić 2004, Xirouchakis \& Tsiakiris 2009, Grubač 2013, Sušić \& Radek 2013, Velevski et al. 2013, Demerdzhiev et al. 2014). The Griffon Vulture population in Bulgaria has steadily increased in the past 30 years as a result of intensive conservation actions and reintroduction programmes (Dobrev \& Stoychev 2013, Demerdzhiev et al. 2014, Stoynov et al. 2018).

Lead is a highly toxic heavy metal with an important impact on bird populations. Absorption of a low concentration of lead may result in a wide range of sublethal effects in animals, and higher concentrations may result in acute intoxication and consequent death. It is an accumulative metabolic poison that is non-specific, affecting a wide range of physiological and biochemical systems including the hematopoietic, vascular, nervous, renal, immune and reproductive systems (Franson \& Pain 2011, Pain et al. 2019).

Lead poisoning originating from ammunitions is a well-known threat for wildlife species on a global scale (Plaza et al. 2018, Pain et al. 2019). Evidence of lead intoxication negatively affecting raptor species are documented for many endangered birds such as the Californian Condor Gymnogyps californianus, the Cinereous Vulture Aegypius monachus, the Egyptian Vulture Neophron percnopterus on the Balkans and the Bearded Vulture Gypaetus barbatus in North America, Spain and the Alps (Fry 2003, Rodriguez-Ramos et al. 2008, Bounas et al. 2016, Ganz et al. 2018).

Several mechanisms of lead intoxication are reported in wild birds. Lead from ammunitions dispersed in the environment can be swallowed (Beintema 2001, Scheuhammer et al. 2003), and/or embedded within the bird's tissues after shooting and consequently, accumulated in the blood over time (Finkelstein et al. 2014, LaDouceur et al. 2015).

Griffon Vultures feed on various game species found in the landscape, which puts them at high risk of chronic or acute lead poisoning by ingesting lead pellets embedded in tissues of the shot animals (Carneiro et al. 2016, Arrondo et al. 2020). Juvenile and immature vultures spend their first years of life wandering vast areas in the Middle East, Africa and Asia (Arkumarev et al. 2019) and can become victims of illegal shooting. Some wounded birds survive and continue their way south carrying lead pellets embedded in their tissues. Illegal killing is among the main threats and of great conservation concern in the Eastern Mediterranean countries where annually thousands of raptors and other migratory birds are shot on their way to Africa (Brochet et al. 2019). Demerdzhiev et al. (2014) reports 15.79\% of the Griffon Vultures found dead in Bulgaria from 1979 to 2011 as victims of illegal shooting. However, this threat is considered to bear a low impact on the Griffon Vulture globally (Botha et al. 2017), but yet, there are numerous cases of killed or injured vultures.

The lead intoxication of Griffon Vulture in various aspects is well studied in Spain (García-Fernández et al. 2005, Espín et al. 2014, González et al. 2017, Arrondo et al. 2020). However, the impact and evidence of this threat have not been reported from the Balkans. We present here a case of long-term chronic lead intoxication of a wild Griffon Vulture, tracked with a GPS transmitter and found dead in the Eastern Rhodopes, Bulgaria. 


\section{Materials and methods}

The Griffon Vulture was captured on 25.05.2017 via a walk-in trap in the Eastern Rhodopes, Bulgaria. Based on its plumage, the vulture was aged as an adult (Forsman 2003). Based on a blood DNA sample, the vulture was sexed as a female. The bird was measured at the time of trapping obtaining weight and morphometrics. The vulture was marked with a colour wing tag, a standard metal ring, and a colour ring, to ease its identification in the wild. Blood and saliva samples were collected for toxicological and microbiological analysis. The Griffon Vulture was also fitted with a solar-powered 57g GSM/GPS and accelerometry transmitter (E-Obs GmbH; 132 Munich, Germany) attached as a backpack configuration with $11.2 \mathrm{~mm}$ Teflon ribbon (Arkumarev 2020).

The vulture died on 17.04.2019 in the Eastern Rhodopes, Bulgaria. The body was recovered on the next day in good overall condition. The bird was transported for admission to the Wildlife Rehabilitation and Breeding Centre "Green Balkans" - Stara Zagora (WRBC), where initial external examination and body weight measurement were conducted. A consequent radiography was assigned. A standard gross pathological examination followed. The necropsy was executed to investigate the reasons that led to its death. Sample from femur bone and liver to test for lead $(\mathrm{Pb})$ contents were obtained additionally and sent for quantitative lead tests to an accredited laboratory in Bulgaria.

\section{Results}

The Griffon Vulture was tracked for 692 days in 2017-2019. This period covers partially or entirely three breeding seasons (2017, 2018, 2019). During this period, no successful breeding was recorded by either telemetry data or by visual observations.

The concentration of $\mathrm{Pb}$ in the blood of the bird taken during the tagging was $384.85 \mathrm{ng} / \mathrm{g}(0.385 \mathrm{mg} / \mathrm{kg})$ dry weight (dw). The vulture weighed $7.6 \mathrm{~kg}$. At the time of admission at WRBC, the corpse of the bird weighed $5.880 \mathrm{~kg}$. During the gross external examination, no clues for electrocution, collision, acute poisoning or poaching were recognized.

The radiography detected two foreign metal particles in the bone of the right wing, supposed to be lead pellets (Figure 1). No specific gross organ

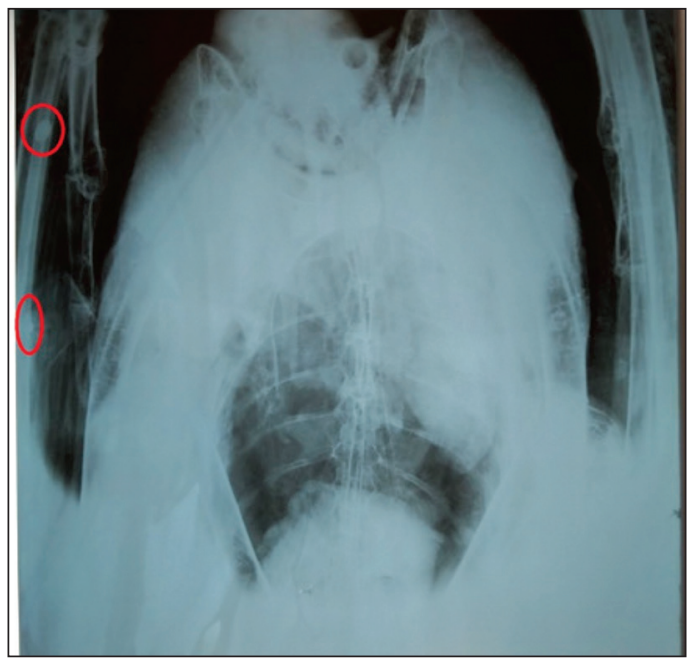

Figure 1. Ventrodorsal X-ray image of the Griffon Vulture with two lead pellets in the right wing

1. ábra A fakó keselyű ventrodorzális nézeti röntgenfelvételén jól kivehető a jobb szárnyban lévő két sörétszem 
lesions were detected during necropsy, however, evidence for hepatic necrosis was observed. Visual inspection of the reproductive organs showed atrophy. Laboratory findings indicated the presence of lead in the analyzed femur and liver samples. The post mortem bone sample resulted in $11.58 \pm 1.16 \mathrm{mg} / \mathrm{kg}$ dw of $\mathrm{Pb}$ in the tissue. Lead levels in the liver tissue were $4.06 \pm 0.41 \mathrm{mg} / \mathrm{kg} \mathrm{dw}$.

\section{Discussion}

In this paper, we document a case of a Griffon Vulture from the Balkan population that was a victim of an illegal shooting and carried lead pellets inside its body. Usually, a period of at least two months is necessary for calcification of bones after injury (Paskalev 2013). The bird was tracked and closely monitored with a GPS transmitter for two years. During this period, abnormal behaviour was not observed, which might suggest that the vulture was shot or injured. This indicates that the pellets have been embedded in the bird's right ulna for a long time. We suggest that the bird was already having the lead pellets calcified when it was captured and tagged as it had the highest Pb blood levels of all Griffon Vultures ( $\mathrm{n}=33$ ) we have tested (Escobar-Gonzales et al. 2020). The vulture weighted $7.6 \mathrm{~kg}$ during tagging that was reduced to $5.88 \mathrm{~kg}$ postmortem, which is considered abnormal weight for a female Griffon Vulture (normal weight between 8-11 kg (Carneiro et al. 2016).

Morphologically, liver lesions in birds were reported as a sign of lead intoxication by Ochiai et al. (1993) and Pikula et al. (2013). The observed dystrophic changes of the reproductive organs of the vulture suggested its inactivity through the last breeding season. We hypothesise that the vulture was not able to breed because it suffered a long-term lead intoxication which affected its overall health and fertility in compliance with the findings of Vallverdú-Coll et al. (2016).

We registered high levels of lead in the bones $(11.58 \pm 1.16 \mathrm{mg} / \mathrm{kg} \mathrm{dw})$ of the vulture. Bone lead concentration is generally the best indicator of lead exposure over the lifetime of a bird (Franson \& Pain 2011). Bone lead concentration higher than $10 \mathrm{mg} / \mathrm{kg}$ dry weight is considered as inflated and levels higher than $20 \mathrm{mg} / \mathrm{kg}$ are associated with clinical signs of acute lead intoxication (Mateo et al. 2003, Plaza \& Lambertucci 2018).

We recorded $\mathrm{Pb}$ values of $4.06 \pm 0.41 \mathrm{mg} / \mathrm{kg}$ dry weight, equal to $1.31 \mathrm{ppm}$ wet weight (ww) after conversion, in the liver, which appeared to be consistent with the findings of LaDouceur et al. (2015). The author reported these levels to correspond with subclinical elevations of hepatic lead in nine cases of dead wild birds with radiographically evident gunshot projectiles in the tissues (0.29-3.84 ppm ww).

The blood $\mathrm{Pb}$ concentration of the vulture at the time of tagging was $384.85 \mathrm{ng} / \mathrm{g}$, equal to $0.38 \mathrm{ppm}$ and corresponded with an earlier study of U.S. Fish \& Wildlife Service (1990), which found that blood lead values starting from $0.2 \mathrm{ppm}$ is a threshold when toxicity symptoms begin to appear.

However, blood and liver lead concentrations, in our case, were significantly lower than that reported for Griffon Vultures suffered of acute poisoning due to ingestion of lead pellets in another study (Carneiro et al. 2016). In cases of chronic exposure, the highest 
lead concentrations are found in bone with lower concentrations in soft tissues such as liver and blood (Franson \& Pain 2011). We hypothesise that the Griffon Vulture in our study suffered a long-term chronical exposure to lead, possibly from the pellets found in its wing. Consequently, the shot was no life threatening, which allowed the bird to live long enough to accumulate lead over the threshold levels. A study of the diet of Griffon Vultures in the Eastern Rhodopes (Arkumarev et al. 2021) reports cause of mortality for 93 specimens used for food by the vultures, $4.3 \%$ of which were hunted or poached. Lead could also have accumulated over time as a result of ingestion of lead pellets with the food. However, blood samples from 32 other Griffon Vultures from the same population did not indicate elevated lead concentrations (Escobar-Gonzales et al. 2020).

Lead is a highly toxic heavy metal that acts as nonspecific poison affecting all body systems. Absorption of low concentrations may result in a wide range of sublethal effects on animals, and higher concentration may result in mortality (Franson \& Pain 2011). Little is known about the origin of the lead pellets in our case, however, it is an evidence of poaching. Significant numbers of young Griffon Vultures from Eurasia migrate to the Middle East and Africa. A GPS tracked Griffon Vulture from the same colony in the Eastern Rhodopes, Bulgaria, has reached South Sudan in Africa (Arkumarev et al. 2019). There are estimates that at least 1.7-4.6 million birds of at least 413 species may be killed or taken illegally each year in the countries of the Middle East (Arabian Peninsula, Iran, Iraq) (Brochet et al. 2019). Consequently, the bird could have been shot somewhere in its wandering, overwintering or resident areas. That case stresses that lead poisoning in birds from ammunition occurs in different forms and may lead to physiological changes in the individual that affect its reproduction capacity and threaten its life.

That issue needs to be explored at a larger scale as it is currently unknown how many vultures are victims of such illegal practices. There is a need for further exploration of illegal shootings along the species' flyway and also in the residential areas in Bulgaria.

\section{Acknowledgements}

This work was initiated and financially supported by the LIFE project "Conservation of Black and Griffon Vultures in the cross-border Rhodope mountains" (LIFE14 NAT/ NL/000901) funded by the European Union.

\section{References}

Arkumarev, V. 2020. Thoracic X-strap harness. Design and method 3. - In: Anderson, D., Arkumarev, V., Bildstein, K., Botha, A., Bowden, C. G. R., Davies, M., Duriez, O., Forbes, N. A., Godino, A., Green, R. E., Krüger, S., Lambertucci, S. A., Orr-Ewing, D., Parish, C. N., Parry-Jones, J. \& Weston, E. (eds.) 2020. A practical guide to methods for attaching research devices to vultures and condors. - Vulture News 78(a): 1-72. IUCN Species Survival Commission Vulture Specialist Group Technical Publication No.1. DOI: $10.4314 /$ vulnew.v78ai1.1

Arkumarev, V., Dobrev, D. \& Stamenov, A. 2019. First record of Eurasian Griffon Vulture Gyps fulvus from the Balkans migrating to South Sudan revealed by GPS tracking. - Scopus 39(2): 27-35. 
Arkumarev, V., Dobrev, D., Stamenov, A., Terziev, N., Delchev, A. \& Stoychev, S. 2021 Using GPS and accelerometry data to study the diet of a top avian scavenger. - Bird Study 673: 300-310. DOI: 10.1080/ 00063657.2020 .1864285

Arrondo, E., Navarro, J., Perez-García, J. M., Mateo, R., Camarero, P. R., Martin-Doimeadios, R., C. R., JiménezMoreno, M., Cortés-Avizanda, A., Navas, I., García-Fernández, A. J., Sánchez-Zapata, J. A. \& Donázar, J. A. 2020. Dust and bullets: Stable isotopes and GPS tracking disentangle lead sources for a large avian scavenger. - Environmental Pollution 266(3): 115022. DOI: 10.1016/j.envpol.2020.115022

Beintema, N. 2001. Lead Poisoning in Waterbirds. International Update Report 2000. - Wetlands International, Wageningen

BirdLife International 2020. IUCN Red List for birds. - Downloaded from http://www.birdlife.org on 26/11/2020.

Botha, A. J., Andevski, J., Bowden, C. G. R., Gudka, M., Safford, R. J., Tavares, J. \& Williams, N. P. 2017. Multispecies Action Plan to Conserve African-Eurasian Vultures. - CMS Raptors MOU Technical Publication No. 5. CMS Technical Series No. 35. Coordinating Unit of the CMS Raptors MOU, Abu Dhabi, United Arab Emirates

Bounas, A., Ganoti, M., Giannakaki, E., Akrivos, A., Vavylis, D., Zorrilla, I. \& Saravia, V. 2016. First confirmed case of lead poisoning in the endangered Egyptian Vulture (Neophron percnopterus) in the Balkans. - Vulture News 70: 22-29. DOI: 10.4314/vulnew.v70i1.2

Brochet, A., Jbour, S., Sheldon, R., Porter, R., Jones, V., Fazari, A., Saghier, O., Alkhuzai, S., Al-obeidi, L., Angwin, R., Ararat, K., Pope, M., Shobrak, M. \& Willson, M. 2019. A preliminary assessment of the scope and scale of illegal killing and taking of wild birds in the Arabian Peninsula, Iran and Iraq. - Sandgrouse 41: 154-175.

Carneiro, M., Oliveira, P. A., Brandão, R., Francisco, O. N., Velarde, R., Lavín, S. \& Colaço, B. 2016. Lead poisoning due to lead-pellet ingestion in Griffon Vultures (Gyps fulvus) from the Iberian Peninsula. - Journal of Avian Medicine and Surgery 30(3): 274-279. DOI: 10.1647/2014-051

del Hoyo, J., Elliott, A. \& Sargatal, J. 1994. Handbook of the Birds of the World, Vol. 2. New World Vultures to Guineafowl. - Barcelona, Lynx Edicions

Demerdzhiev, D., Hristov, H., Dobrev, D., Angelov, I. \& Kurtev, M. 2014. Long-term population status, breeding parameters and limiting factors of the Griffon Vulture (Gyps fulvus) population in Eastern Rhodopes, Bulgaria. - Acta Zoologica Bulgarica 66(3): 373-384.

DeVault, T. L., Rhodes, O. E. \& Shivik, J. A. 2003. Scavenging by vertebrates: behavioral, ecological, and evolutionary perspectives on an important energy transfer pathway in terrestrial ecosystems. - Oikos 102: 225-234. DOI: 10.1034/j.1600-0706.2003.12378.x

Dobrev, D. \& Stoychev, S. 2013. Vulture conservation in Bulgaria. - Proceedings of the Griffon Vulture Conference, 6-8 March 2013, Limassol

Escobar-Gonzales, M., Herreo-Villar, M., Dobrev, D., Arkumarev, V., Stamenov, A., Zakkak, S., Camarero, P. \& Mateo, R. 2020. Assessment of the exposure to environmental toxics in free-living European Griffons (Gyps fulvus) and Cinereous Vultures (Aegypius monachus) in the Balkans. - Poster, SETAC, conference, 2020, Dublin, Ireland

Espín, S., Martínez-López, E., Jiménez, P., María-Mojica, P. \& García-Fernández, A. J. 2014. Effects of heavy metals on biomarkers for oxidative stress in Griffon Vulture (Gyps fulvus). - Environmental Research 129: 59-68. DOI: 10.1016/j.envres.2013.11.008

Finkelstein, M. E., Kuspa, Z. E., Welch, A., Eng, C., Clark, M., Burnett, J. \& Smith, D. R. 2014. Linking cases of illegal shootings of the endangered California Condor using stable lead isotope analysis. - Environmental Research 134: 270-279. DOI: 10.1016/j.envres.2014.07.022.

Forsman, D. 2003. The Raptors of Europe and the Middle East. A Handbook of Field Identification. - T \& AD Poyser, London

Franson, J. C. \& Pain, D. J. 2011. Lead in birds. - In: Beyer, W. N. \& Meador, J. P. (eds.) 2011. Environmental Contaminants in Biota. - CRC Press, USA, pp. 563-593.

Fry, M. 2003. Assessment of lead contamination sources exposing California Condors. - Final Report, University of California, pp. 85.

Ganz, K, Jenni, L., Madry, M., Kraemer, T., Jenny, H. \& Jenny, D. 2018. Acute and chronic lead exposure in four avian scavenger species in Switzerland. - Environmental Contamination and Toxicology 75: 566-575. DOI: 10.1007/s00244-018-0561-7

García-Fernández, A., Martínez-López, E., Romero, D., María-Mojica, P., Godino, A. \& Jiménez-Montalbán, P. 2005. High levels of blood lead in Griffon Vultures (Gyps fulvus) from Cazorla Natural Park (southern Spain). - Environmental Toxicology 20: 459-463. DOI: 10.1002/tox.20132. 
González, F., López, I., Suarez, L., Virginia, M. \& Rodríguez, C. 2017. Levels of blood lead in Griffon Vultures from a Wildlife Rehabilitation Center in Spain. - Ecotoxicology and Environmental Safety 143: 143-150. DOI: 10.1016/j.ecoenv.2017.05.010.

Grubač, B. 2013. Vulture status and conservation in Serbia. - In: Andevski, J. (eds.) Vulture Conservation in the Balkan Peninsula and Adjacent Regions. - 10 Years of Vulture Research and Conservation, Skopje, pp. 30-33.

LaDouceur, E. E., Kagan, R., Scanlan, M. \& Viner, T. 2015. Chronically embedded lead projectiles in wildlife: A case series investigating the potential for lead toxicosis. - Journal of Zoo and Wildlife Medicine 46: 438442. DOI: 10.1638/2015-0026R.1.

Mateo, R., Taggard, M. \& Meharg, A. A. 2003. Lead and arsenic in bones of birds of prey from Spain. Environmental Pollution 126: 107-114. DOI: 10.1016/S0269-7491(03)00055-1

McGrady, M. \& Gavashelishvili, A. 2006. Tracking vultures from the Caucasus into Iran. - Podoces 1(1-2): 21-26.

Ochiai, K., Jin, K., Goryo, M., Tsuzuki, T. \& Itakura, C. 1993. Pathomorphologic findings of lead poisoning in White-fronted Geese (Anser albifrons). - Veterinary Pathology 30: 522-528.

Pain, D., Mateo, R. \& Green, R. 2019. Effects of lead from ammunition on birds and other wildlife: A review and update. - Ambio 48: 935-953. DOI: 10.1007/s13280-019-01159-0.

Paskalev, M. 2013. Veterinary radiology. - In: Borisov, I. \& Goranov, N. (eds.) KOTA-PRINT, Stara Zagora

Pikula, J., Hajkova, P., Bandouchova, H., Bednarova, I., Adam, V., Beklova, M., Kral, J., Ondracek, K., Osickova, J., Pohanka, M., Sedlackova, J., Skochova, H., Sobotka, J., Treml, F. \& Kizek, R. 2013. Lead toxicosis of captive vultures: case description and responses to chelation therapy. - BMC Veterinary Research 9: 11. DOI: 10.1186/1746-6148-9-11

Plaza, P. \& Lambertucci, S. 2018. What do we know about lead contamination in wild vultures and condors? A review of decades of research. - Science of the Total Environment 654: 409-417. DOI: 10.1016/j. scitotenv.2018.11.099.

Plaza, P. I., Uhart, M., Caselli, A., Wiemeyer, G. \& Lambertucci, S. A. 2018. A review of lead contamination in South American birds: the need for more research and policy changes. - Perspectives of Ecology and Conservation 16: 201-207. DOI: 10.1016/j.pecon.2018.08.001.

Rodriguez-Ramos, F. J., Gutierrez, V., Höfle, U., Mateo, R., Monsalve, L., Crespo, E. \& Blanco, J. 2008. Lead in griffon and cinereous vultures in central Spain: correlations between clinical signs and blood lead levels. Proceedings: Ingestion of Spent Lead Ammunition: Implications for Wildlife and Humans

Scheuhammer, A. M., Bond, D. E., Burgess, N. M. \& Rodrigue, J. 2003. Lead and stable isotope ratios in soil, earthworms and bones of American Woodcock (Scolopax minor) from eastern Canada. - Environmental Toxicology and Chemistry 22: 2585-2591.

Stoynov, E., Kmetova-Biro, E., Stoyanov, G., Peshev, H., Ivanov, I., Stoev, I., Bonchev, L., Vangelova, N., Nikolova, Z., Iankov, L., Parvanov, D. \& Grozdanov, A. 2018. Population boost of the Griffon Vulture (Gyps fulvus Hablizl, 1783) (Accipitridae) in Bulgaria based on reintroductions. - Acta Zoologica Bulgarica Suppl. 12: 59-65.

Sušić, G. 2004. The situation of the Griffon Vulture in Croatia. - In: Slotta-Bachmayr, L., Bögel, R. \& Camina, A. (eds.) The Eurasian Griffon Vulture (Gyps fulvus fulvus) in Europe and the Mediterranean. - Status Report and Action Plan, Salzburg: East European/Mediterranean Griffon Vulture Working Group, pp. 32-36.

Sušić, G. \& Radek, V. 2013. Vulture status and conservation in Croatia. - In: Andevski, J. (ed.) Vulture Conservation in the Balkan Peninsula and Adjacent Regions. - 10 Years of Vulture Research and Conservation, Skopje, pp. 16-19.

U.S. Fish and Wildlife Service. 1990. Lead poisoning in waterfowl. - U.S. Fish and Wildlife Service, Washington, D.C., pp. 1-15.

Vallverdú-Coll, N., Mougeot, F., Ortiz-Santaliestra, M. E., Castaño, C., Santiago-Moreno, J. \& Mateo, R. 2016. Effects of lead exposure on sperm quality and reproductive success in an avian model. - Environmental Science and Technology 50: 12484-12492. DOI: 10.1021/acs.est.6b04231.

Velevski, M., Lisitchanets, E. \& Lisitchanets, T. 2013. Vulture status and conservation in Macedonia. - In: Andevski, J. (ed.) Vulture Conservation in the Balkan Peninsula and Adjacent Regions. - 10 Years of Vulture Research and Conservation, Skopje, pp. 26-29.

Xirouchakis, S. \& Tsiakiris, R. 2009. Status and population trends of vultures in Greece. - In: Donázar, J. A., Margalida, A. \& Cambion, A. (eds.) Vultures, feeding stations and sanitary legislations: a conflict and its consequences from the perspective of conservation biology. - Donostia, Aranzadi, pp. 154-171. 